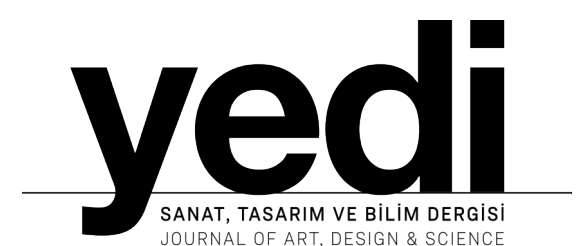

SANAT, TASARIM VE BILIM DERGISI
Araştırma Makalesi

Research Article

\title{
Sanatta Geleneğin Döngüsü: Güncel İmgelerin Geleneksel İmgelerden Yeniden Üretilmesi
}

\author{
The Cycling of Tradition in Art: Reproduction of Contemporary Images from Traditional Images \\ Niyazi Değirmenci, Seramik Bölümü, Hacettepe Üniversitesi \\ Kaan Canduran, Seramik Bölümü, Hacettepe Üniversitesi
}

\begin{abstract}
Özet
$\mathrm{Bu}$ çalışmada sanatta gelenek kavramının belli bir döneme sıkışmış bir zaman dilimi olarak düşünmek yerine, bu kavramın güncel ve gelenek kavramlarıyla karşıt ilişkisi göz önünde bulundurularak birbirini beslediği ileri sürülmüştür. Aynı şekilde güncel kavramının da zaman-mekân düzleminde gelenek kavramı içinde konumlandığı öne sürülmüștür. Bu bağlamda geçmișten günümüze uzanan sanat çalışmalarındaki imgelere geleneksel imgeler, bu imgelerden yeniden üretilenlere güncel imgeler ön tanımı getirilmiştir. Bu tanımlar ışığında, yeni ve güncel kavramları da tartışılarak diyalektik bir süreç gerektiren, kendinden öncekini olumsuzlayabilen, kopuş-kesintiye neden olabilen bir yeni kavramı önerilmiştir. Güncel kavramı ise belirli bir șimdide aktif bir an olarak tanımlanmıștır. Bu nedenle güncel, rutin süreci belirli bir şekilde aşma isteği ve süreci olarak görülebilirken, gelenek günümüze kadar devamlılık ile ilişkilendirilebilmektedir.

Günümüz güncel sanatında temellük sanatı gibi alternatif yeniden üretim eğilimler, Cindy Sherman, Ai Weiwei, Marina Abramovic gibi pek çok sanatçı tarafından tercih edilmektedir. Bu sanatçıların eğilimleri, geleneksel imgeleri yeniden üreterek yeni ve güncel bir tavırla ilişkilendirilebilir. Ancak bu yeni ve güncel yaklaşımı beraberinde bazı çelişkileri getirmekte, geleneksel olanı pekiştirmekte ve güncel imgenin geleneksel imgeye bağımlılığı saptanabilmektedir. Dolayısıyla bu çalıșma, geleneksel ve güncel imgelerin temsillerini karşılaştırmalı bir yöntemle analiz ederek varsayılan saptamaları deşifre etmeyi amaçlamaktadır.
\end{abstract}

Anahtar Sözcükler: Geleneksel imge, güncel imge, gelenek, modern, yeniden üretim, temellük sanatı.

Akademik disipin(ler)/alan(lar): Görsel sanatlar, sanat felsefesi.

\begin{abstract}
In this study, instead of considering the concept of tradition in art as a timeframe stuck in a certain period, it has been argued that this concept feeds each other by considering its opposite relationship with the concepts of contemporary and tradition. Likewise, it has been suggested that the concept of contemporary positions itself in the concept of tradition in the time-space plane. In this context, traditional images in artworks are defined as images; those reproduced from these images are defined as modern images. In light of these definitions, the concepts of new and modern have also been discussed; and the concept of new has been proposed, which requires a dialectical process, can negate the previous one, and can cause breakinterruption. The concept of contemporary is defined as an active moment in a particular present. Therefore, while modern can be seen as the will and process of transcending the routine process in a certain way, tradition can be associated with continuity up to the present.

Alternative reproduction trends such as appropriation art in today's contemporary art are preferred by many artists such as Cindy Sherman, Ai Weiwei, and Marina Abramovic. These artists tendencies can be associated with a new and modern attitude by reproducing traditional images. However, this approach for new and modern brings along some contradictions, reinforces the traditional, and the dependence of the current image to the traditional image can be detected. Consequently, this study aims to decipher the assumed determinations by analyzing the representations of traditional and modern images with a comparative method.
\end{abstract}

Keywords: Traditional images, contemporary images, tradition, modern, reproduction, appropriation art.

Academical disciplines/fields: Visual arts, philosophy of art.

- Sorumlu Yazar: Niyazi Değirmenci, Seramik Bölümü, Güzel Sanatlar Enstitüsü, Hacettepe Üniversitesi.

- $\quad$ Adres: Hacettepe Üniversitesi, Beytepe Kampüsü, Adatepe Mahallesi, 06800, Çankaya, Ankara.

- $\quad$ e-posta: niyazi.degirmenci@hacettepe.edu.tr

- ORCID: 0000-0003-3197-2788

- Cevrimiçi yayın tarihi: 01.11 .2021

- doi: $10.17484 /$ yedi.948682 


\section{Giriş}

Gelenek, geçmişten günümüze kadar varlığını sürdüren bir toplumun kültürel öğelerinin toplamını ifade edebilen bir kavramdır ve onu ortak kılan, toplum tarafından bu öğelere atfedilen değerlerdir. Öte yandan, sanat üretimindeki gelenek, bu değerlerle bağlantılı olarak ortaya çıkmaktadır. Ancak sanatta gelenek kavramına, geçmişten günümüze toplumların değerlerinin bir yansıması olarak ya da zanaat unsurlarının bir yansıması olarak bakmak, bu çalışmanın kapsamını sınırlayacaktır. Zira, bu çalışmada sanatta gelenek, klasik modernleșme teorisinin sunduğu tartıșmaya göre değil; geçmișin, bugünün ve geleceğin sürekliliğine gömülü, güncel anlamdaki modern kavramıla iç içe olan ve birbirini destekleyen bir ilişkiye dayanmaktadır. Bașka bir deyișle, güncel ve gelenek kavramlarını iki ayrı bir yapı olarak değil, birbirleri ile sürekli ilișki içinde olduğu önerilmiștir. Bu bağlamda örneklenen geçmiş dönem sanat eserleri, dönemlerinde modern ya da güncel olmalarına rağmen günümüz sanatının güncel paradigmaları dikkate alınarak geleneksel olarak tanımlanmıştır. Geleneksel olarak; Raffaello Sanzio'nun La Fornarina'sı, Henry Wallis'ın Chatterton'un Ölümü (The Death of Chatterton), Konyukhov'un Komünizmin Zaferi Kaçınılmazdır'ı (The Victory of Communism is Inevitable), Michelangelo Buonarroti'nin Pietà'sı, Théodore Géricault'ın Savașan Subay'ı (The Charging Chasseur), ve son olarak Vladimir Tatlin'in Tatlin'in Kullesi (Tatlin's Tower) sınıflandırılmıștır. Buna karșı olarak; Cindy Sherman'ın İsimsiz\#205'i (Untitled \#205), Sam Taylor Wood'un Monolog I'i (Soliloquy I), Wang Guangyi'nin Büyük Eleştiri: Coca-Cola'sı (Great Criticism: Coca-Cola), M. Abramović ve Ulay'ın Pietà'sı ve Ai Weiwei'nin Yapım Aşamasında - Işı k Pınarı (Working Progress -Fountain of Light) güncel sanat örnekleri olarak seçilmiştir.

Güncel sanatta bir imge üzerinden yapılan kendine mâl etme, temellük etme, yeniden dolașıma sokma, kopyalama, taklit etme, değiştirme, atıfta bulunma, alıntılama yöntemlerinin kullanımı sanatçlar tarafından yaygınlaşmaktadır. Bu açıdan günümüz sanatçılarının önceki eserleri bu yöntemlerle yeniden ürettikleri ve bu üretimle bir geleneğe dahil oldukları, öncekilere göre çoğaltılan güncel sanat eserlerinin de orijinal olanı bulanıklaştırdığı tartışılmıștır. Walter Benjamin, bu durumu teknik olarak yeniden üretim teknolojisinin yaygınlaşmaya başladığı bir dönemde tespit etmiştir: "Yeniden-üretim teknolojisinin çoğaltılan nesneyi gelenek katmanından ayırmasını genel bir formül olarak sunabiliriz. Yapıtın birden çok çoğaltılmasıyla, onun biricik varlığının yerine kitlesel bir varlık konulur" (Benjamin, 2015, s. 16). Öte yandan Nicolas Bourriaud bu yeniden üretim dönemini postprodüksiyon olarak tanımlamıștır:

Ön ek "post" herhangi bir olumsuzlama ya da așma ișareti tașımaz; bir etkinlik alanına gönderme yapar. Burada sorgulanan işlemler, tümüyle özentili bir duruş olacak olan imgelerin yeni imgelerini üretmek ya da her şey “çoktan yapıldı” diye yas tutmak değil; var olan tüm temsil formları ve tüm biçimsel yapılar için kullanım protokolleri yaratmaktan oluşur. (Bourriaud, 2004, s. 29)

Bu tür yeniden üretim fikri, imgelerden imge üretmenin niyeti, özenti veya çoktan yapıldı düşüncesi değil; temellük sanatının sanat tarihinde yeniden üretme eğiliminde olan sanat eserleri arasındaki ayrıma işaret eden temsil biçimleri ve biçimsel yapılarla bir protokol oluşturduğu argümanıdır. Ancak bu çalışmada, protokol (taahhüt) argümanı, güncel imgelerin geleneksel imgelere bir bağımlılık gösterip göstermediği bağlamında ele alınmıștır. Diğer bir ele alınan konu da sanatçıların yeniden üretim yoluyla yeni ve güncel bir fenomene ulaşıp ulaşamayacağıdır. Bu amaçla ilk olarak yeni ve güncel kavramları temellendirilmiştir.

Bergson'un metafizik anlayışı düşünüldüğünde her an kuşkusuz kendi içinde bir yeni ve güncel barındırır, ancak bununla birlikte yenilikten yenilenen, öncekinden bașkalașan, ayrıșan, kopuș-kesintiyi dolayısıyla öncekini olumsuzlayabilen, öncekini içerip aşma yetisi ve iradesini gösterebilen bir yeni ve güncel kavramı öne sürülmüştür. Bu önermeyle, yeni ve güncel, rutinleşen sürecin belli bir biçimde aşılması iradesi ve süreci olarak görülebilirken, gelenek tarihten bugüne uzanan süreklilik ile ilișkilendirilmiştir. Bu bağlamda, önceki dönemlerden günümüze kadar varlığını sürdüren sanat eserlerindeki imgelere geleneksel imgeler, bunlardan yeniden üretim yapılan çalıșmalara güncel imgeler ön tanımı getirilmiştir. Çalıșma, bu iki ayrı kategoride olan sınıflandırmanın aslında iki ayrı kategoride bile olamayacağını, gelenek kavramı bağlamında aslında varlıksal (ontolojik) anlamda bir olduğunu iddia etmiştir. Bununla birlikte, geleneksel imgelerden güncel imgeler üreten sanatçılar, çeşitli temaları gelenekten bağımsız bir şekilde kullanıyor gibi görünmektedirler. Ancak bu sanatçıların seçtikleri temalarda karșı çıktıkları olgu ne olursa olsun, bizatihi olarak kendilerinin buna dönüştüğü de incelenmiştir. Tüm bu çelişkiler ekseninde, geleneksel imgelerden güncel imgeler üreten sanat çalışmalarının hükümsüz olup olmadığı da sorgulanmıştır. 
Ayrıca, bu çalışmanın literatürde var olan çalışmalardan farkları şu şekilde sıralanabilir:

1. Geleneksel imgelerden yeniden üretilen güncel imgelerin varsayılan benzerlikleri odak noktası olarak alınmıştır. Böylelikle geçmişten günümüze kadar gelebilen imgeleri öncelikle tespit etmiş ardından bunları karşılaştırmalı bir yöntemle analiz etmiştir.

2. Yeniden üretim eğilimi ile elde edilen yeni ve güncel kavramlarını irdeleyerek geleneğin döngüsündeki bir güncel sanat yaklaşımının vaatlerini deşifre etmeyi konu almıştır.

3. Sadece temellük sanatına değil, imgeler aracılığıyla yeniden üretime odaklanarak güncel imgelerin geleneksel imgelere bağımlılık durumunu tartışmıştır.

Özetle çalışmanın amacl, öncelikle bir gelenek modeli oluşturmak, bu model ile birlikte güncel (modern) karşılaştırmasında bulunmak, bu bağlamda gelenek kavramı ile yeniden üretilen güncel sanat eserlerinin nasıl bir ilişkide olduğunu ortaya çıkarmak ve vaat edilen yeniden üretimin yeni ve güncel savlarını karşılaştırmalı örneklerle irdelemektir. Böylece, tarihte kült bir konumda olan geleneksel imgeler ile alenen üretilen güncel imgeler, sanatta gelenek döngüsü bağlamında varsayılan argümanları temellendirmek için yeni ve güncel kavramları ıșığında karşılaştırmalı olarak analiz edilmiştir.

\section{Gelenek Kavramı ile Güncel (Modern) Kavramı Arasındaki İlişki}

Kavram olarak gelenek ve modern, geçmişten günümüze pek çok disiplinlerde tartışllan ve güncelliğini koruyan bir ikilik olma özelliğini taşımaktadır. Ancak bu araştırmada, gelenek-modern ikiliği birbirlerinden bağımsız iki karşıt zıt kutup olarak değil, bütünleşik bir yapıyla ele alınacaktır. Ayrıca, Oxford Learner's Dictionaries'e göre modern, up to date terimi ile eş anlamlıdır ve bu çalışmada kullanılan modern kavramı; güncel, zamane ve anda anlamlarına tekabül etmektedir.

Gelenek kavramını Özlem (2016, s. 141), "Latince transdare fiilinden türetilmiş bir akraba fiil olarak tradere, günlük yaşamda depozitle, emanetle, emanetçilikle ilgili bir anlama sahiptir" șeklinde tanımlamıştır. Giddens ise gelenek kavramını yinelenen hareketli bir fenomen olarak açıklamıştır:

\section{(...) belirli bir etkinlik ya da deneyimi, yineleyen toplumsal uygulamalarla yapılanmış olan geçmişin, bugünün ve geleceğin sürekliliği içine yerleştiren bir zaman ve uzam kullanma yoludur. Bütünüyle durağan da değildir, çünkü önceki kuşaklardan kültürel mirasını devralan, her yeni kuşak tarafından yeniden icat edilmek zorundadır. (Giddens, 1994, s. 39-40)}

Etymonline göre (t.y.), modern kavramının etimolojik anlamı ise, Latince modernus terimine dayanan modern terimi, zamansal bağıntının daha belirginlik kazandığı tam şu an anlamına gelen modo'dan türetilmiștir. Hem gelenek hem de modern kavramının zaman olgusunda birleștiği, geleneğin geçmişten modernin ise tam şu an aracılığıyla ilişkili olduğu söylenebilir; geleneğin geçmişten devam eden devingenliğine karşı modus olarak modern, güncel veya belirli şimdide aktif bir rol oynayan an olduğu vurgulanmıştır.

Touraine (2002, s. 39) “Aklın utkusuyla özleştirilen modernlik, geleneksel Bir, yani Varlık arayışının en son biçimidir" sözüyle, şimdideki yeni olan şeyin nihayetinde zaman-uzam kapsamındaki geleneğe tekabül edeceğini ima etmektedir. Genç ve Tezcan'ın da işaret ettiği gibi, günümüzde güncel olarak etkisini sürdürmeyen şeylerin gelenek kapsamında incelenebileceği ve bu noktadan hareketle her sanat eserinin kendi döneminin moderni olduğu söylenebilir (Genç ve Tezcan, 2015, s. 147). Zira, güncel sanatı postmodern sanat olarak tanımlayan ve modern sanatın da kendi içerisinde güncel olarak tanımlandığını vurgulayan İlge'nin düşüncesi, gelenek kavramının kapsayıcılığına, güncel kavramının ise değişkenliğine ışık tutmaktadır (İlge, 2020, s. 45). Bu bağlamda güncel, rutinleşen sürecin belli bir biçimde aşılması iradesi ve süreci olarak görülebilirken, gelenek tarihten bugüne uzanan süreklilik ile ilişkilendirilebilir. Bu nedenle, klasik dönemden günümüze sürekliliğini koruyan sanat eserlerindeki imgelere geleneksel imgeler, bunlardan yeniden üretim yapılan çalışmalara güncel imgeler tanımı getirilebilir. Bu çerçevede, tarihte kült bir konumda olan geleneksel imgelerden yeniden üretilen güncel imgeler, rutinleşen sürecin üstesinden gelme bağlamında karşılaştırmalı bir yöntemle çözülebilir. Aynı zamanda, Mangion'un da ifade ettiği gibi (2015, s. 157), "geleneklerin bir toplumun süregiden varlığını, başka bir deyişle, yeniden üretimini mümkün kılan koşulları oluşturmaları bakımından dinamik olduğu" düşüncesi temellendirilebilir. 


\section{Sanatta Yeni ve Güncel Kavramlarıla Yeniden Üretim}

Güncel sanat öncesinde de imgeleri kendine mâl etme (temellük) veya yeniden üretme konusunda çeşitli eğilimler bulunmaktadır. Ancak bu yeniden üretimin en belirgin eğilimi, temellük sanatıdır. Cambridge Dictionary’e göre (t.y.), temellük kelimesinin İnglizce'deki appropriation kelimesine karşı gelmesi, başkasına ait bir şeyi alma eylemi olarak tanımlanmaktadır. Bu bağlamda, güncel sanatta imgeleri doğrudan yeniden üreten temellük sanatı, sanatsal anlamda alıntı ve gönderme yaparak bilinçli bir parodi olușturduğu da söylenebilir. Ancak, bu parodiyi Artun (2013), sanat tarihinin geri-dönüșümüne kapılan, avangard dahil bütün geleneği yağmalayan postmodern bir strateji olarak görmektedir. Artun'a göre, bu strateji geçmiş dönemdeki sanat eserlerini kopyalayarak, yeniden üreterek veya alıntı yaparak modern sanatın biricikliğine, orijinalliğine ve benzersizliğine zarar vermektedir. Dolayısıyla bu stratejinin modern sanatın orijinallik, özgünlük ilkesini de kopyaladığı ve sahte olanın orijinalin yerine geçtiği, sahte sanat meşrulaştıkça orijinalliğin tespit edilmesinin de güçleştiği söylenebilir (Artun, 2013). Bu düşünceye ek olarak, temellük sanatının geleneği yağmalarken bile geleneğin içerisinde kaldığı, başka bir deyişle yağmaladığı şeyin kendisi olduğu, Baudrillard’ın sözleriyle söylersek (2014, s. 51), hakikaten hükümsüz olduğu ortadadır.

Bourriaud, orijinali belirsizleştiren temellük sanatını Duchamp'ın hazır nesnesinden hazır imgelere geçen postprodüksiyon olarak tanımlar; "Sanat, bir keresinde Duchamp'ın dediği gibi, "tüm devrin insanları arasında süren bir oyun değil midir?" Postprodüksiyon bu oyunun çağdaş biçimidir" (Bourriaud, 2004, s. 31). Bununla birlikte, bu çağdaş oyun dolaylı olarak geleneksel ayrımı da kırmaya çalışmaktadır:

(...) giderek daha fazla sanatçı başkaları tarafından yapılmış çalışmaları ya da hâlihazırdaki kültürel ürünleri yorumluyor, yeniden üretiyor, yeniden sergiliyor veya kullanıyor. (...) Kendi işlerini diğer insanların işlerine yerleştiren bu sanatçılar, üretim ve tüketim, yaratı ve kopya, hazır-nesne orijinal iş arasındaki geleneksel ayrımın kökünün kazınmasında rol oynuyorlar. Manipüle ettikleri materyal birincil değildir artık. Bundan böyle önemli olan ham materyali temel veri olarak alan bir formun ayrıntılarıyla ele alınması meselesi değil, kültürel pazarda çoktan dolaşımda olan nesnelerle (...) çalışma meselesidir. (Bourriaud, 2004, s. 22).

Ancak, Marcel Duchamp'ın Çeşme’sini hazır-nesne kullanarak yeni bir fenomene ulaştığı söylenebilirken, temellük sanatında hazır-imge kullanılması sadece yeniden-yeni bir fenomen haline getirme çabası olduğu söylenebilir. Zira, sanatsal soru artık, 'Nasıl yeni olan bir şey ortaya çıkarabiliriz?' değil; 'Elimizdekilerle nasıl bir şey yapabiliriz?' dir. Başka bir deyişle, 'Günlük yaşamımızı oluşturan bu kaotik nesneler, isimler ve referanslar yı̆̆ınından nasıl tekillik ve anlam üretebiliriz?' sorusudur (Bourriaud, 2004, s. 28). Bergson'un metafizik anlayışı, her anın şüphesiz yeni ve güncel olduğu ilk sırada yer alabilir; her an zaten yeni ve kaçınılmaz olarak öncekilerden farklıdır, ancak ikinci bir görüş olarak yenilikten yenilenen bir bakış da sunulabilir. Yeksan'ın da ifade ettiği gibi, bu bakıș açısı Bergson'un bakıș açısına neredeyse yakın bir șekilde yenilikten, yani yeni olanın tekrarlanmasından hareket ederken öte yandan da artık geçmiște kalanın bașka bir yeniden ayrılmasından gelmektedir. Çünkü sanatta yenilik kavramı, hem kopuşu-kesintiyi dolayısıyla başkasının ya da öncekinin olumsuzlanmasında hem de sürekliliğinde rol oynayabilir. Yani bir öncekini hem içine alan hem de aşan yeni kavramından bahsetmek mümkün. Bu bağlamda yeninin ortaya çıkmasının diyalektik bir süreç gerektirdiği söylenebilir (Yeksan, 2021).

Rajchman, çağdaş (güncel) anların yeni fikirleri olanaklı kılarken eskileri de üst üste bindirme yoluyla yeni bir ışıkla donatan, onlara taze bir actualité, yeni bir çağdaşlık (güncellik) kazandıran Deleuze'ün 'yersizyurtsuzlaştırma' düşüncesini sunar bu da yeniliğin içsel bir geleneğe cevapla ya da cevap verme yükümlüğüyle belirlenemeyeceğini gösterir (Rajchman, 2012). Bu bağlamda, Bourriaud'un sorularını cevaplayabilecek yeni kavramı, öncekilerini (geleneksel imgeleri) olumsuzlayabilen, aşabilen ve bir kopuşa yani ötekine uzanan diyalektik bir süreç şeklinde betimlenebilir. Dolayısıyla, sanatta yeni ve güncel kavramları zaten bir geleneğe bağımlı olmama potansiyeline sahiptir. Ancak temellük sanatı, tüm bu potansiyellerden bağımsız olan bir sirkülasyonda kendisini zımnen yeni ve güncel olarak konumlandırmaya çalışır.

Tarihsel modellerin temellük edilmesinin arkasında, süreklilik ve gelenek oluşturma ve bir kimlik kurgusu inșa etme arzusu olabileceği gibi, bütün kodlaştırma sistemleri üzerinde evrensel bir hâkimiyet kurma isteği de yatabilir (...) Her temellük edimi bir dönüştürme vaadidir: her el koyma edimi, o farazi başkalaşımı öngörür. Ama başkalaşım yerine, tam da temellükün deva olmayı 
vaat ettiği șeyleșmeyi yaratır ve kalıcılaștırır. (...) Dolayısıyla her kültürel temellük edimi, ikili bir yadsıma simülakrumu inșa eder: hem bireysel ve özgün üretimin geçerliliğini, hem de özgül bağlamın önemini ve eserin kendi pratiğinin işlevini aynı ölçüde inkâr eder. (Buchloh, 2018)

Bașka bir gelenekselleșmiş imgeden yeni olanı keșfetmek, bu keșiften güncel bir sonuç elde etmeyi amaçlayan temellük sanatında yeni ve güncel kavramlarına artık şüpheyle yaklaşılabilir. Zira, yeniden üretilen güncel sanatın imgeleri, tarihte devamlılık açısından kendini kanıtlamış olan geleneksel imgelerle zaten iç içe geçmiş haldedir. Bugün geleneksel imgeler var olmasaydı, yeni ve güncel bir yana, yeniden üretilen imgelerin kendisi hiç var olamayacaktı ki bu da iç içe geçmişliğin temel referansını oluşturmakta, varlıksal (ontolojik) bir probleme işaret etmektedir. Örneğin, yeniden üretimin popüler imgelerinden Mona Lisa'ya tarihsel bağlamda kabul gördüğü için geleneksel bir imge olarak ele alınırsa, ondan üretilen yeni imgeler Mona Lisa'yı -geleneği- sürekli olarak pekiștirecektir. Yeniden üretilen Mona Lisa, izleyicinin zihninde bağımsız-ayrık bir yeni ve güncel yaratamadan tarih boyunca kabul gören gelenek döngüsünden kurtulamayacaktır. Bu bağlamda geleneksel imgelere atfedilen yeni ve güncel olgularının günümüz sanatının yeni ve güncel olan ile çeliştiği, var olan geleneği pekiştirdiği ve yapısal yönüyle zaten bir oldukları argümanlarına ulașılabilmekte; dolayısıyla her yeniden üretim eğilimini de temellük sanatının kapsamı ile birlikte değerlendirilebilmektedir.

\section{Güncel İmgelerin Geleneksel İmgelerden Yeniden Üretilmesi}

Sanatta imge, "dış gerçekliğin zihinde yeni bir bedene kavuşması ve sonrasında bir gösterge olarak tekrar görünür olma halidir. Zihnin içerisinde birçok suret meydana gelir ve imge olarak açığa çlkar. İmge olarak var olan geçeklik yeni bir varlık olarak kendini imler" (Altaş, 2018, s. 1). Aynı şekilde, Sartre'ın (2009, s. 8), "çalışma masamda bulunan yaprak, aynı yaprak kuşkusuz, ama bir biçimde var oluyor. Tek kelimeyle, fiilen var olmuyor, imge olarak var oluyor" örneğindeki gibi en genel ifadeyle, gerçekliğin zihindeki yansıması olarak tanımlanabilir.

Eğer imge, gerçekliğin zihindeki yansıması olarak tanımlanırsa, geleneksel imge, -bir önceki bölümün referansıyla- geçmişten günümüze gelebilen zihindeki yansımalar, şeklinde tanımlanabilmektedir. Bu bağlamda sanatçılar, yeni bir biçim dili elde edebilmek için zaman veya dönem farklılığının etkisini koruyan bu geleneksel imgelere yönelik alternatif bir eğilim göstermişlerdir. Başka bir ifadeyle tekrarlanan imgeler, artık gelenekselleştiği anlam ve biçimden farklı, dönemin güncelliğiyle sanatçıların aracıllğıyla yeni ve güncel bir anlatı biçimi oluşturulmak istenmiştir. Ancak, bu yeni ve güncel vaat pek çok çelişkiyi de beraberinde getirmiştir. Bu çelişkiyi serimlemek için Cindy Sherman, Sam Taylor-Wood, Wang Guangyi, Marina Abramović ile Ulay, Kehinde Wiley ve son olarak Ai Weiwei gibi sanatçlların çalışmaları örnek olarak seçilmiştir.

Bir bukalemun gibi kendi kişisel imgesini çok farklı kimlikler üzerinden yüzlerce defa çoğaltan ve kendi gerçek kimliğinden vazgeçerek bunu dağıtmayı hedefleyen Cindy Sherman, kültürün birçok merkezlerinden alıntılanmış figür örnekleri sunmuştur (Ersu, 2013, s. 6). Cinsiyet, kimlik, aidiyet gibi temaları güncel sanatta yeniden üreten Sherman, İsimsiz\#205 çalışmasında (Şekil 2), Raffaello'nun Fornarina'sına atıfta bulunur (Şekil 1). Sanat tarihindeki erkek egemenliğine gönderme yapan sanatçı, bunu yaparken doğrudan sanat tarihindeki geleneksel imgeyi kendisine mâal eder. Ancak, kadının doğurganlığını feminist bir ifadeyle yansıtmak isterken, "getirilebilecek en temel eleştiri karşı çıkılan tutum ve durumların bir anlamda devamını sağladı̆̆ı olur" (Kelleci, 2018). Zira Sherman, erkek egemenliği üzerinden gelenekselleşen imgeyi değiştirmeye çalışsa da değiştirmek istediği şeyin kendisi olur; geleneğin döngüsünde konumlanır, bir dönüşüm vaadi başlamadan biter. Dolayısıyla hem bireysel hem de özgün üretimin gerçekliği aynı ölçüde inkâr edilerek diyalektik olmayan yeni ve güncel bir senaryo kurgulanmış olur.

Sam Taylor Wood'un yapıtındaki güncel imge, kendisinden neredeyse 150 yıl önceden yaratılmış bir geleneksel imgeyle yeniden örtüşür. Güncel, ölü bir bedeni izleyiciye anlatmak için 150 yıl önceden yapılmış olan Wallis'in tablosundan imgelenmiş; geleneğin ölü bedeni olan Chatterton, Taylor'un güncelinde yeniden hayat bulmuştur (Şekil 3). Taylor'un ölü bedeni, artık genel geçer bir ölü bedeni değil; Chatterton'un ölü bedeninin imgelemidir. Wallis'in tablosundaki kompozisyonun güçlü ifadesi, Taylor tarafından pekiştirilerek yeniden üretilmiştir (Şekil 4). Taylor'ın Monolog I (Soliloquy I) filminin karesindeki sonsuz sayıda üretilebilecek ölü beden kompozisyonu yerine, imge alenen The Death of Chatterton ile birleşmiștir. Yani güncel ve yeni olan imge, geleneğin döngüsel akışında kaldığı görülebilmektedir. 


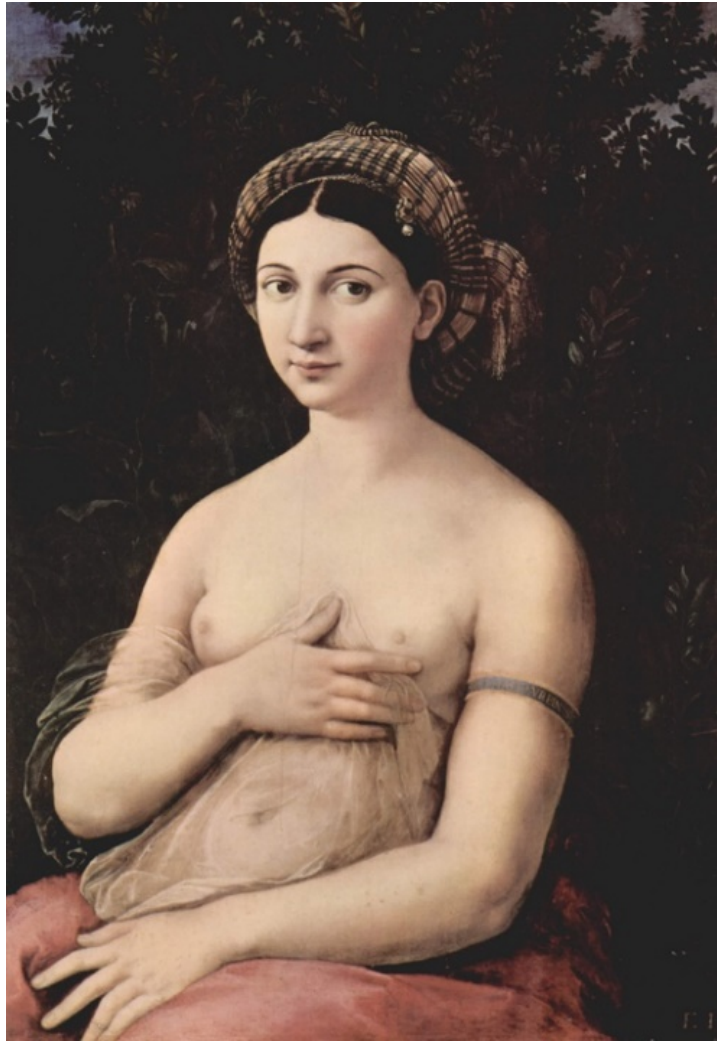

Şekil 1. La Fornarina, R. Sanzio. 1518/1519.

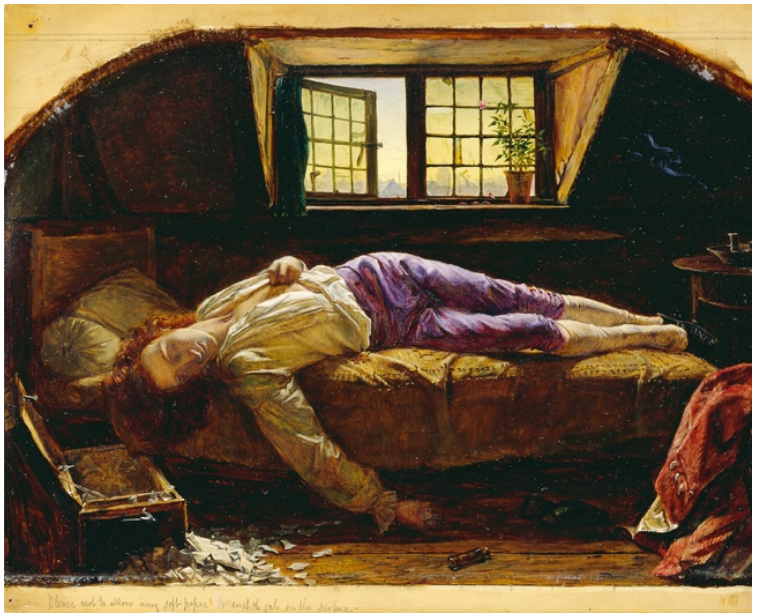

Şekil 3. The Death of Chatterton, H. Wallis, 1856.

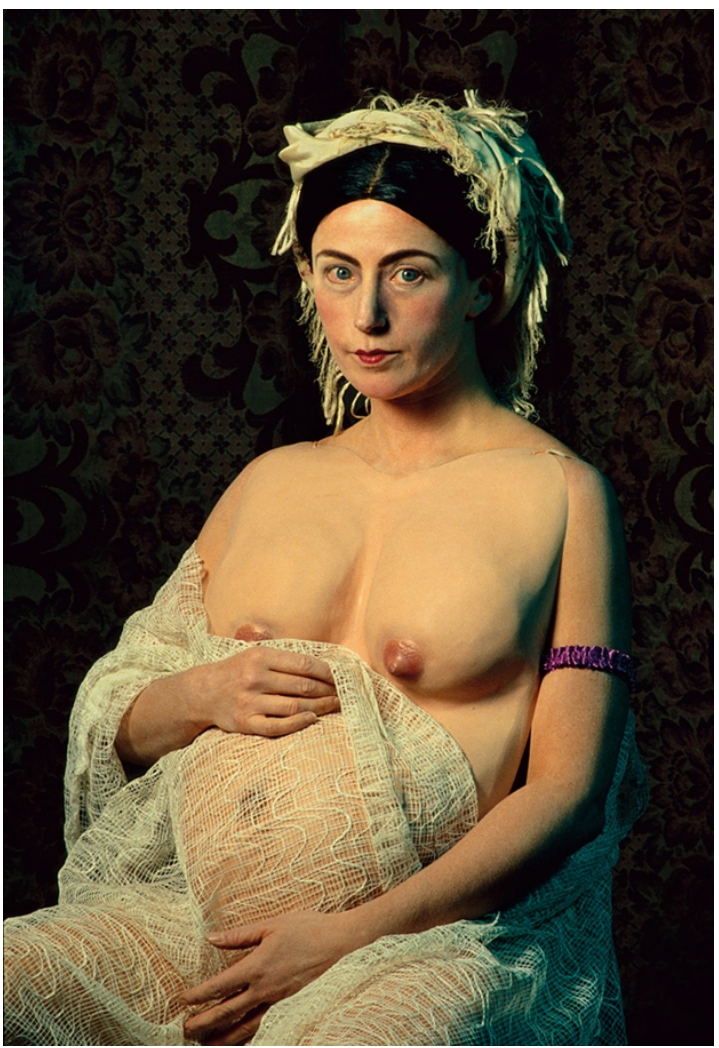

Şekil 2. Untitled\#205, C. Sherman 1989.

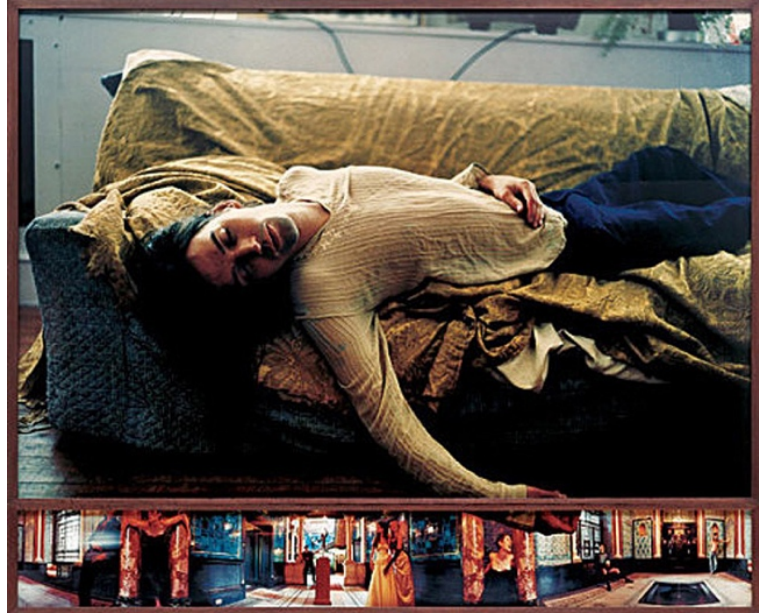

Şekil 4. Soliloquy I, S. T. Wood, 1998.

Geleneksel imgelerin yeniden üretilmesi sadece kompozisyon veya biçim ile sınırlı değil, bu durum kendisini politik bir tavır şeklinde de gösterebilir. Sosyalist dönemde propaganda amacıyla yapılmış Lenin'in parmak ucuyla gösterdiği yöne doğru sert kontur çizgileriyle elinde meşale tutan güçlü işçi imgesi (Şekil 5), Guangyi tarafından yeniden üretilmiștir. Bu iki imge arasında zamansal veya dönemsel ciddi bir fark olmamasına rağmen Guangyi, bu imgeyi kapitalizmin simgeleriyle birlikte kompoze etmiştir (Şekil 6). Bu bütünlükte, Guangyi'nin çalışmasıyla güçlü olan işçi imgesi bir başka gücün içerisinde kendisini var etmiş; hedef ve yön gösterilen işçiler, kapitalizmin imgesinde güçlerini ve birlikteliklerini yeniden konumlandırmıştır. Neticede gelenekselleşmiş olan güçlü işçi imgesi, bir bütün halde yeniden üretilerek iki kutuplu siyasi bir propagandaya dönüştürülürken, bunu alternatif bir işçi karakteriyle değil, zihinlere yerleşmiş olan hali hazırda bulunan geleneksel imgeyle yapmıştır. Bu durumda Guangyi sosyalist bir güçlü işçi imgesini kullanarak kapitalizme karşı büyük bir eleştiri getirdiğini vaat etmiştir. Ancak Guangyi, geleneksel imge aracılığıyla kapitalizmi olumsuzlamak istese de olumsuzlamak istediği şeyin kendisini kopyalayarak kendi hükümsüzlüğünü inşa etmiştir. 


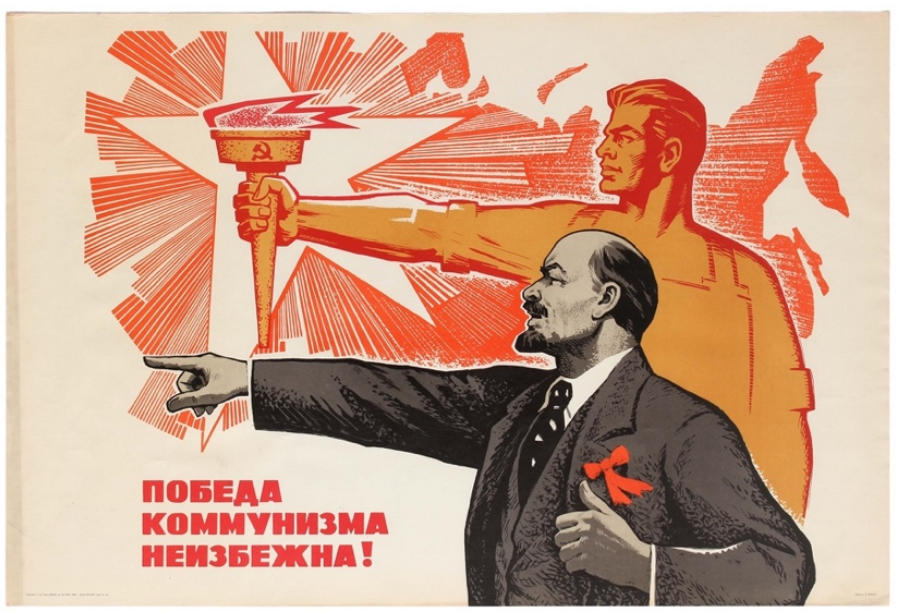

Şekil 5. The Victory of Communism is Inevitable, V. Konuhov, 1969.

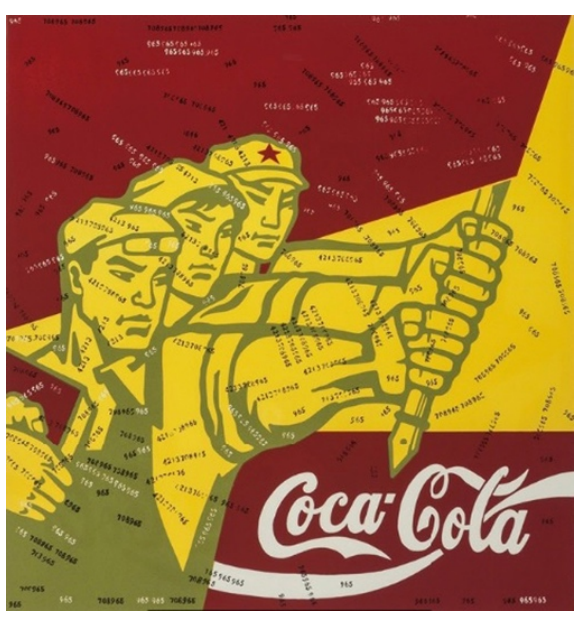

Şekil 6. Great Criticism: Coca-Cola, W. Guangyi, 2006.

Zamanın ötesinde şu anın güncelinde yeniden üretilmiş imgeler, din-mit olgularından da açık bir şekilde beslenmiş, Michelangelo'nun Pietà'sı (Şekil 7) ile Abramovic ve Ulay'ın Pietà'sı (Șekil 8) kendi güncel döneminin biçim ve anlam kayglları gözeterek yeniden üretilmiștir. İsa'nın ölü bedenini kucağında tașıyan Meryem imgesi, kronolojik olarak her dönemde vücut bularak günümüze kadar ulaşmıştır. Bu geleneği devam ettiren en güncel sanatçlardan biri olan Abramovic, sadece izleyiciye sıradan bir hüzün duygusunu aktarmaz; alenen Meryem'in hüznünü de aktarmış olur. Abramovic günümüz güncel sanatında Meryem'i kendi vücudunda temsil etmesi, bunca yıldır algılanan ve gelenek ile günümüze ulaşan Meryem Ana'ya özgü güç-şefkat imgesini kendisine mal ederken, Ulay'ın İsa'ya atfedilen huzur imgesini kendisine mâl etmek istediği söylenebilir. Bu nedenle güncel sanat pratiklerinde kaybolmuş gibi görünen gelenek, Abramovic tarafından yeniden üretilmiş; öncekini içerip aşamayan, ötekine ulaşamayan bir yeni ve güncel eğilim sergilemiştir.

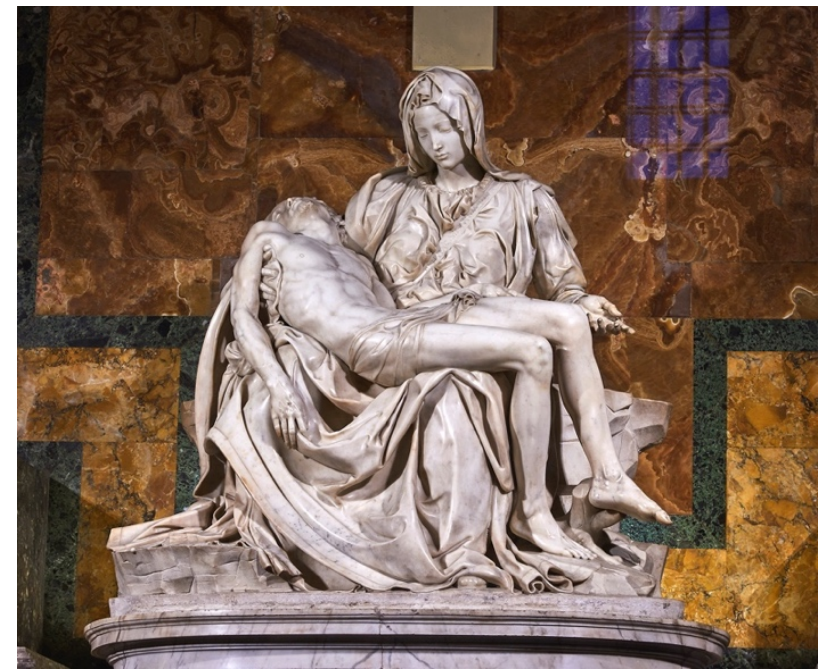

Şekil 7. Pietà, B. M. Michelangelo, 1498/1499.

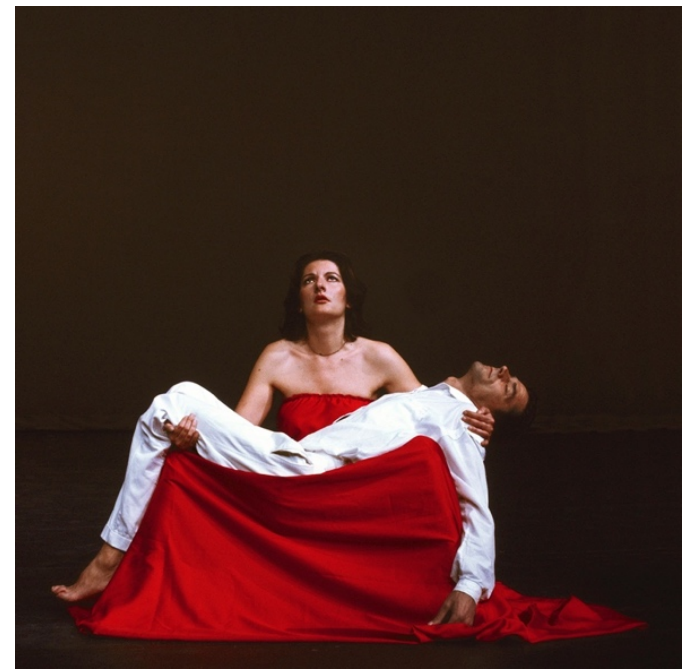

Şekil 8. Pietà, M. Abramović ve Ulay, 1983/2002.

Yine Abramovic gibi Kehinde Wiley, kendisini Géricault'un gün ıșığına doğru atı șahlanmış imparatorluğun gücünü imgeleyen Savaşan Subay (The Charging Chasseur) yerine alenen kendisini koymuştur (Şekil 9 ve 10). Yaklaşık 200 yıl sonra güncellenen bu geleneksel imgede, siyahilerin de Batı medeniyeti ve sanatında güçlü ve egemen olabileceğini göstermek istemiştir. İmparatorluğu temsil eden bu güç ve egemenlik imgesi, tekrar ortaya çıkma firsatı bulmuş; güncel olan gelenekle birlikte yeni bir ifade aracına dönüştürülmek istenmiştir. Nihayetinde Wiley'in güç ve egemenlik içerikli çalışması sıradan bir imgeden değil, zaten geçmişten günümüze güç ve egemenliği aktarabilen, tarihsel olarak hazır geleneksel bir imgeden gelmektedir. Ancak Wiley, beyazların egemenliğini eleştirirken, eleştirdiği şeyi arzuladığı halde ne kendisini 
ne de siyahların egemenliğini inşa edebilmiştir. Aksine, Wiley'in geleneksel imgeyi yeniden üretmesi, karşı olduğu şeyin kalıcılığını meşrulaştırmıştır.

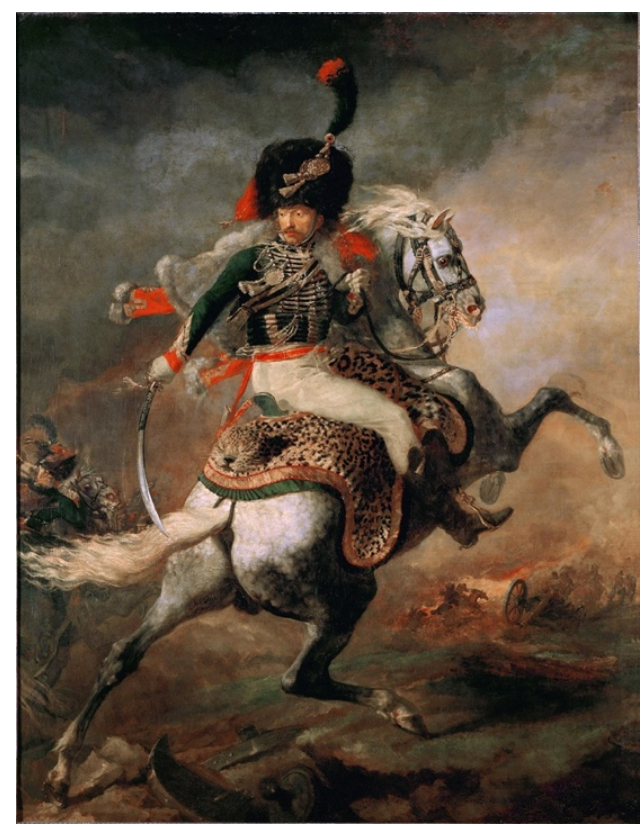

Şekil 9. The Charging Chasseur, T. Géricault, 1812.

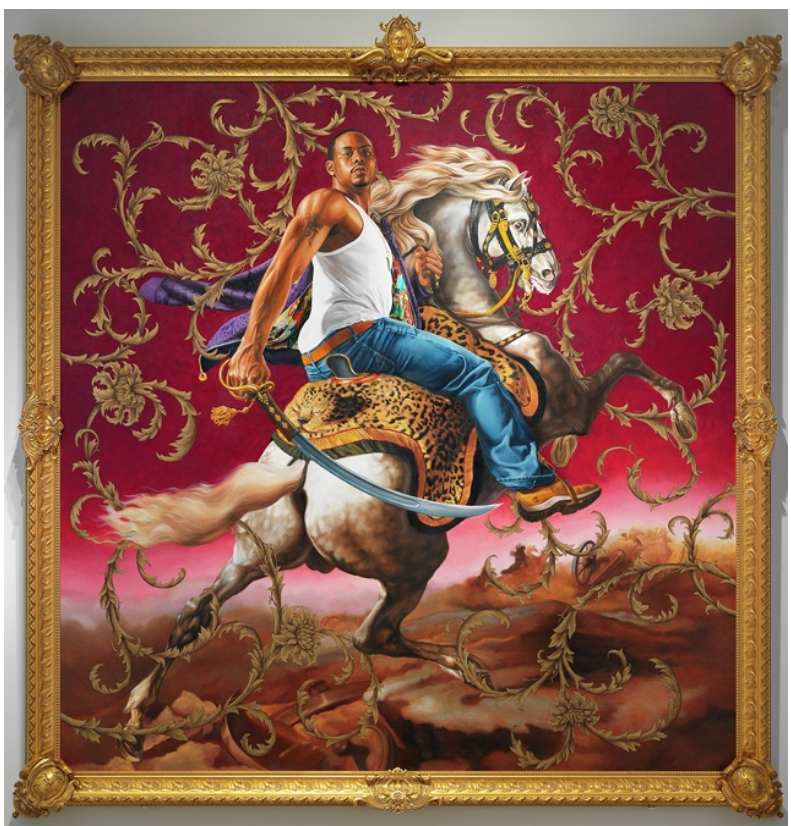

Şekil 10. Officer of the Hussar, K. Wiley, 2007.

"Savaşın yol açtığı düşmanlıkları, kardeşçe bir iş birliği içinde ortadan kaldırmayı ve uluslararası sosyalizmi birliğe kavuşturmayı amaçlayan Üçüncü Enternasyonal'e bir Anıt olarak ısmarlanan Tatlin'in Kulesi, aynı zamanda Paris'teki Eifel Kulesine bir yanıt olacaktı" (Şekil 11) (Lynton, 2015, s. 104-105). Bu hedeflere ulaşılmadan sadece zihinde ilerlemeyi veya gelişmeyi imgeleyen bu anıtın modelleri çeşitli ülkelerde yeniden üretilmekte ve sergilenmektedir. Ai Weiwei ise 2007 yllında Liverpool'da bu anıtı yeniden üreterek sergilemiştir (Şekil 12).

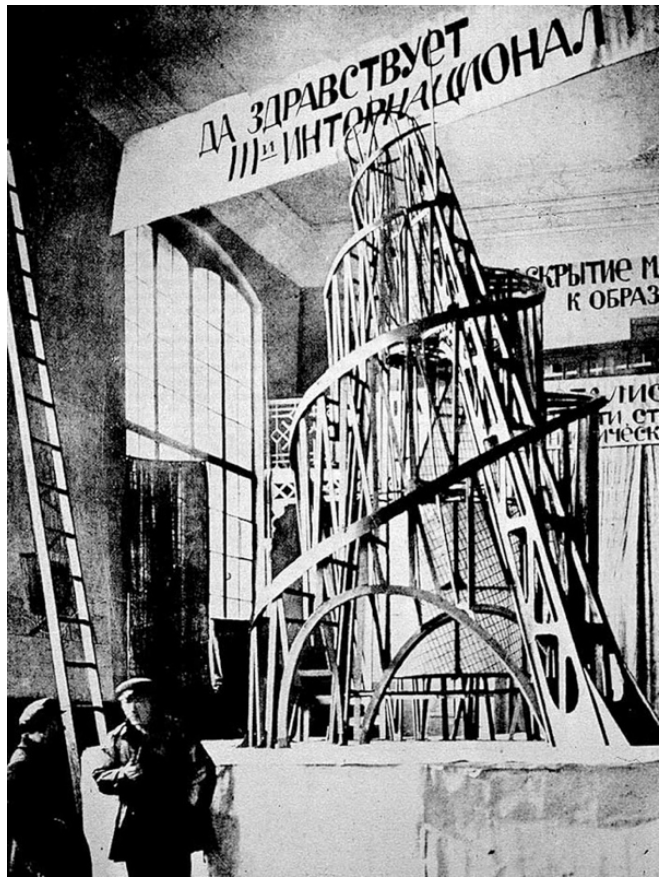

Şekil 11. Tatlin's Tower, V. Tatlin, 1920.

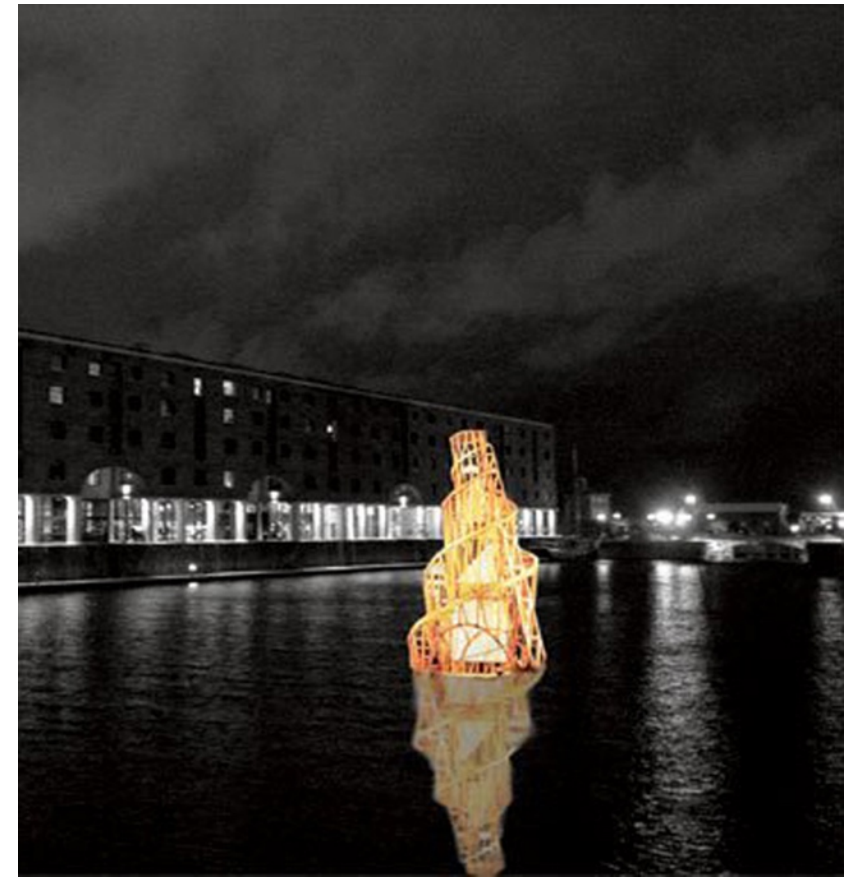

Şekil 12. Working Progress (Fountain of Light), A. Weiwei, 2007.

Weiwei, savaş sonrası dönemin kaygılarının hala güncel bir mesele olduğunu, canlı ve dinamik bir şekilde su üstünde durduğunu izleyicilere göstermek istemiştir. Nitekim Weiwei, ilerlemenin ve gelişmenin 
aktarımını yapacak herhangi bir imgeden değil, zaten geçmișten günümüze kadar gelebilen ve zihinlere yerleșebilen geleneksel bir imgeden almıștır; yani sanatçı, geleneksel imgelerin gücünden yararlanmayı ve bununla bugün yeni bir ifade aracı oluşturmayı diğer sanatçllar gibi denemiştir. Ancak Weiwei'nin çalışması yeninin tekrarına dayanırken, diğer yandan geleneksel hale gelen bir başka yeniden ayırt edilememektedir. Dolayısıyla bu durum onu Tatlin Kulesi'ne bağımlı, otonom olmayan varlıksal (ontolojik) olarak bir şeye dönüștürebilir.

Tüm bu sanatsal pratikler, biçimsel olarak heterojen olmakla birlikte, hepsi de daha önce üretilmiş olan formları bir yardım aracı olarak kullanırlar. Sanat işini özerk ya da orijinal bir form olarak değerlendirmektense, onu göstergeler ve anlamlardan oluşan bir ağ içine yerleştirmeye ilişkin bir hevesi gözler önüne sererler. Burada söz konusu olan, ortak boş bir yap-boz tahtasından başlama ya da hiç dokunulmamıș bir materyale dayanarak bir anlam yaratma değil, üretimin sayısız akışlarıyla kesişme yolunu bulma meselesidir (Bourriaud, 2004, s. 28).

\section{Sonuç}

Temellük sanatını da kapsayan geleneksel imgelerden güncel imgeler üreten yeniden üretim eğilimi, yeni ve günceli nasıl gün yüzüne çıkaracağı ve kendisini referanslar yığınından nasıl kurtaracağı konusunda cevap verememektedir. Bunun nedeni, her anın zaten yeni ve güncel olduğu, ancak yenilikten yenilenen bir bakış açısının sanatçılar tarafından tercih edilmediğidir. Dolayısıyla sanatın içsel bir geleneğe cevap verme yükümlülüğü bulunmadığından, geleneksel imgelerden alenen güncel imgeler üreten sanatçıların diyalektik bir yeni ve güncel sunamadığı da söylenebilir. Halbuki sanatın ontolojisindeki yaratım süreci, gelenekselleşen rutini aşma iradesini içerse de sanatçıların bu potansiyelle etkileşime girmediği belirlenebilir. Böylelikle devingen bir gelenek modeliyle, Sherman'dan Weiwei'ye kadar geleneksel imgeler günümüzde yeniden üretilerek güncel sanatın içerisine nüfus ettirilmiş, sanatın döngüsel tutumu daha net ortaya çıkarılmıştır. Bu döngüsellikte, güncel sanatçıların geleneksel imgeleri benimsemesi ile yeniden üretiminin nedenselliği arasında iki çıkarım yapılabilmektedir.

Bu çıkarımlardan ilki, şimdinin geçmişle ilişsisinin bir sonucu olarak geleneksel imgelerden yeni bir fenomen üretme potansiyelinden kaynaklanmaktadır. Böyle bir varsayım, geleneksel imgelerin gücünü yadsınamaz bir şekilde daha çok ortaya çıkarmakta, geleneği pekiştirmektedir. Aynı zamanda Kehinde Wiley, Cindy Sherman ve diğer sanatçıların yapitlarının imgelerin yeniden üretimi ile olumsuzlanması amaçlanan şeye kendilerinin dönüştüğü söylenebilir. Bu durum, sanatçların geleneğin döngüsünü olumsuzlamak, kopuş veya kesinti yaratmak yerine karşıt oldukları şeyi alenen olumsuzlama eğiliminde olduğunu göstermektedir ki bu da sanatçlların yeniden üretim eğilimiyle hem geleneğin döngüsünde kaldıkları hem de orijinali ile birlikte kendilerini de muğlaklaştırdıkları söylenebilir.

İkinci çıkarım ise, Duchamp'ın hazır-nesne anlayışının güncel sanatçıların hazır-imge anlayışına hükümsüz bir şekilde geçtiğidir. Ancak, güncel sanatın hali hazırda günümüze kadar gelen geleneksel imgeleri, -ki günümüze kadar gelenin aynı zamanda güncel olduğunu varsayarsak- tekrar yeni ve güncel olarak sunması, başka bir çelişkiyi de yaratmaktadır. Bu çelişki, geleneğin içindeki döngüselliğin bir parçası olmakla başlayan, tarihsel bir kategoriye dönüşmesiyle sınırlı olan bağımlılıktır. Örneğin Tatlin'in Kulesi (Tatlin's Tower) bugün hiç olmasaydı, Ai Weiwei'nin Yapım Aşamasında-Işılk Pınarı (Working Progress-Fountain of Light) de bugün var olamazdi; bu koşullu ilişki bir taahhüt değil, doğrudan güncelin geleneğe bağımlılı̆̆ıdır.

Böylelikle, güncel sanatta aleni bir şekilde yeniden üretme eğiliminin gelenek sınırları içinde var olduğu, bu eğilimin ister güncel ister modern adı altında faal olsun, geleneği beslediği söylenebilir. Bu bağlamda geleneksel imgeleri yeniden üretmek, “(...) kendilerine dayatılmış tarihsel sınırları kabul etmek ve sembolik bir özgürleşmenin beyhude tekrarıyla o sınırlara riayet etmek" anlamına gelmektedir (Buchloh, 2018). Dolayısıyla, güncel sanatın geleneksel imgeleri yeniden üreterek özgürlüğe olan yanılgısı, geleneğe olan bağımlılığı deșifre olmaktadır.

\section{Kaynakça}

Abramović, M. ve Ulay. (1983/2002). Pietà [Performans]. Lia Rumma Gallery, Napoli. https://www.sothebys.com/en/articles/marina-abramovic-the-cleaner-major-retrospectivecharts-50-years-of-pushing-boundaries 
Altaş, Ș. (2018). İmgenin bakışı. (Tez No. 519972) [Sanatta yeterlilik tezi, Hacettepe Üniversitesi]. Ulusal Tez Merkezi.

Artun, A. (2013, 21 Şubat). Sahte sanat. $e$-skop. https://www.e-skop.com/skopbulten/sahte-sanat/1162

Baudrillard, J. (2014). Sanat komplosu yeni sanat düzeni ve çağdaş estetik 1 (E. Gen ve I. Ergüden, Çev.). İletişim Yayınları.

Benjamin, W. (2015). Teknik olarak yeniden-üretilebilirlik çağında sanat yapıtı (G. Sarı, Çev.). Zeplin Kitap.

Bourriaud, N. (2004). Postprodüksiyon/Senaryo olarak kültür: sanat dünyayı nasl yeniden programlıyor (N. Saybaşli, Çev.). Bağlam Yayınları.

Buchloh, B. H. D. (2018, 28 Mart). Temellük sanatı ve parodi (E. Gen, Çev.). e-skop. https://www.eskop.com/skopbulten/temelluk-sanati-ve-parodi/3739

Cambridge Dictionary. (t.y). Appropriation. Cambridge dictionary içinde. https://dictionary.cambridge.org/tr/sözlük/ingilizce/appropriation

Ersu, B. (2013). Sanatta yeniden anlamlandırma. (Tez No. 356902) [Yüksek lisans tezi, Gazi Üniversitesi]. Ulusal Tez Merkezi.

Etymonline. (t.y.). Modern. Online etymology dictionary içinde. https://www.etymonline.com/word/modern\#etymonline_v_17375

Genç, M. ve Tezcan, V. (2015). Gelenek ve yenilik kavramlarının felsefi tartışması ekseninde geleneksel Türk sanatlarını yeniden düşünmek. Kalemişi Dergisi. 3(6). 135-156.

Géricault, T. (1812). The Charging Chasseur [Yağlıboya]. Louvre Museum, Paris. https://en.wikipedia.org/wiki/The_Charging_Chasseur

Giddens, A. (1994). Modernliğin sonuçları (E. Kuşdil, Çev.). Ayrıntı Yayınları.

Guangyi, W. (2006). Great criticism: Coca-Cola [Litografi Baskı]. The Kwai Po Collection, Hong Kong. https://www.artsy.net/artwork/wang-guangyi-wang-yan-yi-coca-cola-red-from-the-greatcriticism-series

İlge, R. (2020). Küreselleşme ve güncel sanat sorunlarının odağında bir sergi: Magiciens de la Terre. ARTS: Artuklu Sanat ve Beşeri Bilimler Dergisi. 0 (3), 40-56. doi: 10.46372/arts.661836

Kelleci, R. (2018, 2 Mart). Binbir yüzlü Cindy Sherman. 5 Harfliler. https://www.5harfliler.com/binbiryuzlu-cindy-sherman/

Konuhov, V. (1969). The victory of communism is inevitable [Poster]. Musée D'Histoire Contemporaine, Paris. https://www.invaluable.com/auction-lot/propaganda-poster-the-victory-of-communism-is-ine32-c-f3d440ca17

Lynton, N. (2015). Modern sanatın öyküsü (C. Çapan ve S. Öziş, Çev.). Remzi Kitapevi.

Mangion, C. (2015). Gelenek, iletişim ve toplumsal yeniden üretim üzerine. Kaygı. Uludağ Üniversitesi Fen Edebiyat Fakültesi Felsefe Dergisi (E. Yıldızer ve M. Bal, Çev.). 25, 154-168.

Michelangelo, B. M. (1498/1499). Pietà [Mermer Heykel]. Saint Peter's Basilica, Rome. https://tr.wikipedia.org/wiki/Pietà_(Michelangelo)

Oxford Learner's Dictionaries. (t.y). Up to date. Oxford learner's dictionary içinde. https://www.oxfordlearnersdictionaries.com/definition/english/up-to-date

Özlem, D. (2016). Kavramlar ve tarihleri. Notos Kitap Yayınevi.

Touraine, A. (2002). Modernliğin Eleștirisi (H. Tufan, Çev.). Yapı Kredi Yayınları.

Rajchman, J. (2012, 31 Ekim). Çağdaş: Yeni bir fikir mi? e-skop. https://www.e-skop.com/skopbulten/cagdas-estetik-cagdas-yeni-bir-fikir-mi/949\#_edn5

Sanzio, R. (1518/1519). La Fornarina [Ahşap üzerine yağlıboya]. Galleria Nazionale d'Arte Antica, Rome. https://commons.wikimedia.org/wiki/File:Raffael_045.jpg

Sartre, J. P. (2009). İmgelem (A. Tümertekin, Çev.). İthaki Yayınları. 
Sherman, C. (1989). Untitled\#205 [Kromojenik renkli baskı]. The Board. https://www.thebroad.org/art/cindy-sherman/untitled-205

Tatlin, V. (1920). Tatlin's Tower [Anit Heykel]. Model of Tatlin's Tower in the courtyard of the Royal Academy, London. https://en.wikipedia.org/wiki/Tatlin\%27s_Tower

Yeksan, E. (2021, 14 Nisan). 'Yeni'nin diyalektiğine doğru. e-skop. https://www.e-skop.com/skopbulten/ 'yeninin-diyalektigine-dogru/6126

Wallis, H. (1856). The death of Chatterton [Ahşap panel üzerine yağlıboya]. Yale Center for British Art, NH. https://commons.wikimedia.org/wiki/File:Henry_Wallis_-_The_Death_of_Chatterton__Google_Art_Project.jpg

Wiley, K. (2007). Officer of the hussars [Yağlıboya]. Detroit Institute of Arts, Detroit, MI. https://www.dia.org/art/collection/object/officer-hussars-98007

Wood, S. T. (1998). Soliloquy I [Fotoğraf]. Solomon R. Guggenheim Museum, New York. https://www.guggenheim.org/artwork/9408

Weiwei, A. (2007). Working progress (Foundation of Light) [Enstalasyon]. Tate Modern, London. https://www.tate.org.uk/whats-on/tate-liverpool/exhibition/real-thing-contemporary-artchina/real-thing-exhibition-guide-11 